J. Perinat. Med. 12 (1984) 325

\title{
Obstetrical and neonatological aspects of a child with atresia of the small bowel
}

\author{
M. G. M. Bergmans, J. M. W. M. Merkus, A. M. Baars* \\ Department of Obstetrics and Gynecology, Maria Ziekenhuis, Tilburg, \\ The Netherlands \\ * Department of Echography, Maria Ziekenhuis, Tilburg, The Netherlands
}

\section{Introduction}

At the beginning of 1983 a child was born in our hospital with an atresia of the small bowel. The diagnosis was suspected antenatally. In this report we shall discuss the etiology of this malformation and the possibilities of antenatal diagnostics. More and more ultrasonography is creating possibilities for diagnosing malformations antenatally. We have little experience with its consequences.

In presenting this case, we hope to afford insight into the etiology of bowel atresia and to contribute to the discussion concerning the handling of antenatally diagnosed malformations.

\section{Case report}

A 32 year old gravida 2, para 1 was admitted to the hospital at the 31 st week of pregnancy because she had not felt any fetal movements for about 2 days. Before admission, the pregnancy was uneventful. At admission fetal growth was normal, but the fetal heart rate trasing demonstrated a rate of $165 \mathrm{bpm}$ with almost no variability and with mild decelerations (Fig. 1). This pattern continued during admission. Fetal movements could be seen by real-time ultrasonography. The BPD was $7.7 \mathrm{~cm}$ (P 25). The amount of amniotic fluid was normal. There were no visible malformations. Our patient was asked to count fetal movements daily. The frequency increased slowly up to 30 movements in

\section{Curriculum vitae}

MARTIN BERGMANS was born in 1953. He studied Medicine at the University of Utrecht and graduated in 1978. Afterwards he was resident in internal medicine and surgery. Since 1980 he has worked as a resident in the department of Obstetrics and Gynecology in the Maria Hospital in Tilburg.

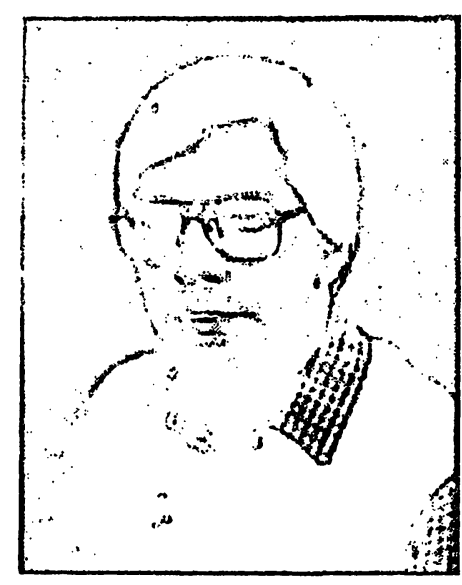

one hour after 2 days, which can be considered normal [15]. There were no disturbances in carbohydrate metabolism.

A week after admission the abdominal diameter of the mother increased. It was now comparable with a pregnancy of 36 weeks. Polyhydramnios was suspected. At this time ultrasonography showed a fetus with a distended stomach, duodenum and small bowel. More lateral in the fetal abdomen a structure was observed which could not be clearly identified (Fig. 2). An obstruction or atresia of a part of the fetal small bowel was suspected. Amniocentesis was performed under ultrasonography. Green amniotic fluid was obtained. Laboratory examination gave the following results: $\mathrm{L} / \mathrm{S}$ ratio 2.0 , TPL $125 \mu \mathrm{Mol} / 1$, protein $5.72 \mathrm{~g} / \mathrm{l}$, urea $4.8 \mathrm{mmol} / 1$, alkaline phosphatase $1494 \mathrm{U} / \mathrm{l}$ and bilirubin $\Delta$ O.D. 0.240. Since the amenorrhea was only 32 weeks, there were no other signs of 


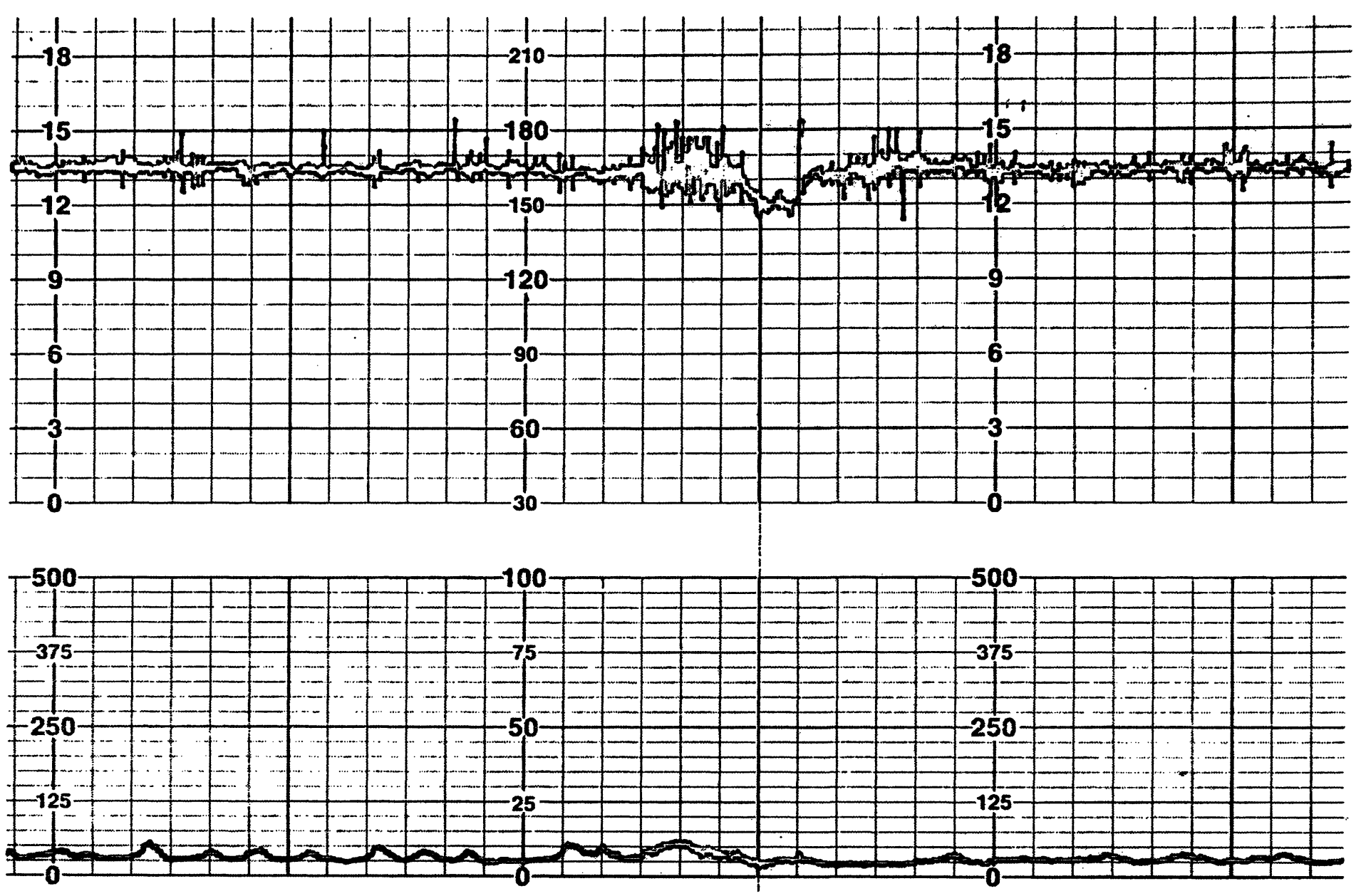

Fig. 1. Representative part of the cardiotachogram at admission $(1 \mathrm{~cm} / \mathrm{min})$.

fetal distress and a congenital malformation was suspected. We decided to continue the pregnancy and to observe our patient closely.

After 33 weeks of pregnancy our patient came in active labor. Since she was multigravida and the fetus was in a vertex position, we anticipated a vaginal delivery. Amniotomy was performed for better observation of the fetus. About $3000 \mathrm{cc}$ of meconium stained amniotic fluid was obtained. Afterwards there were marked decelerations in fetal heartrate. Because this pattern persisted we decided upon a ceasarean section.

A depressed girl was born with a bradycardia. The APGAR score at 1 minute was 2 . The arterial blood from the umbilical cord showed a $\mathrm{pH}$ of 7.20 , a $\mathrm{PCO}_{2}$ of $56 \mathrm{mmHg}$ and a base excess of $-6.7 \mathrm{mmol} / \mathrm{l}$. The child was carefully suctionated by laryngoscope and a great deal of meconium was removed. The child was then intubated and insufflated with $100 \%$ oxygen. It recovered quickly.
An hour later its condition had improved greatly and only a slight respiratory acidosis remained ( $\left.\mathrm{pH} 7.30, \mathrm{PCO}_{2} 53.7 \mathrm{mmHg}, \mathrm{BE}-1.5 \mathrm{mmol} / 1\right)$.

Examination of the abdomen showed a tumor on the left side with a diameter of about $8 \mathrm{~cm}$. The surface was smooth. An X-ray of the thorax was suggestive of meconium aspiration. An X-ray of the abdomen showed calcifications in the upper part as described with meconium peritonitis [19]. Because serious intraabdominal malformations were suspected, the child was transported to a department of pediatric surgery. Surgery was performed on the same day. An atresia of the ileum and a volvulus were discovered together with perforation of the small bowel and meconium peritonitis. A pseudocyst was the result. The atretic part was resected liberally. The jejunum and the last $50 \mathrm{~cm}$ of the ileum could be retained which was enough to guarantee bowel function. Postoperatively there were no problems. 

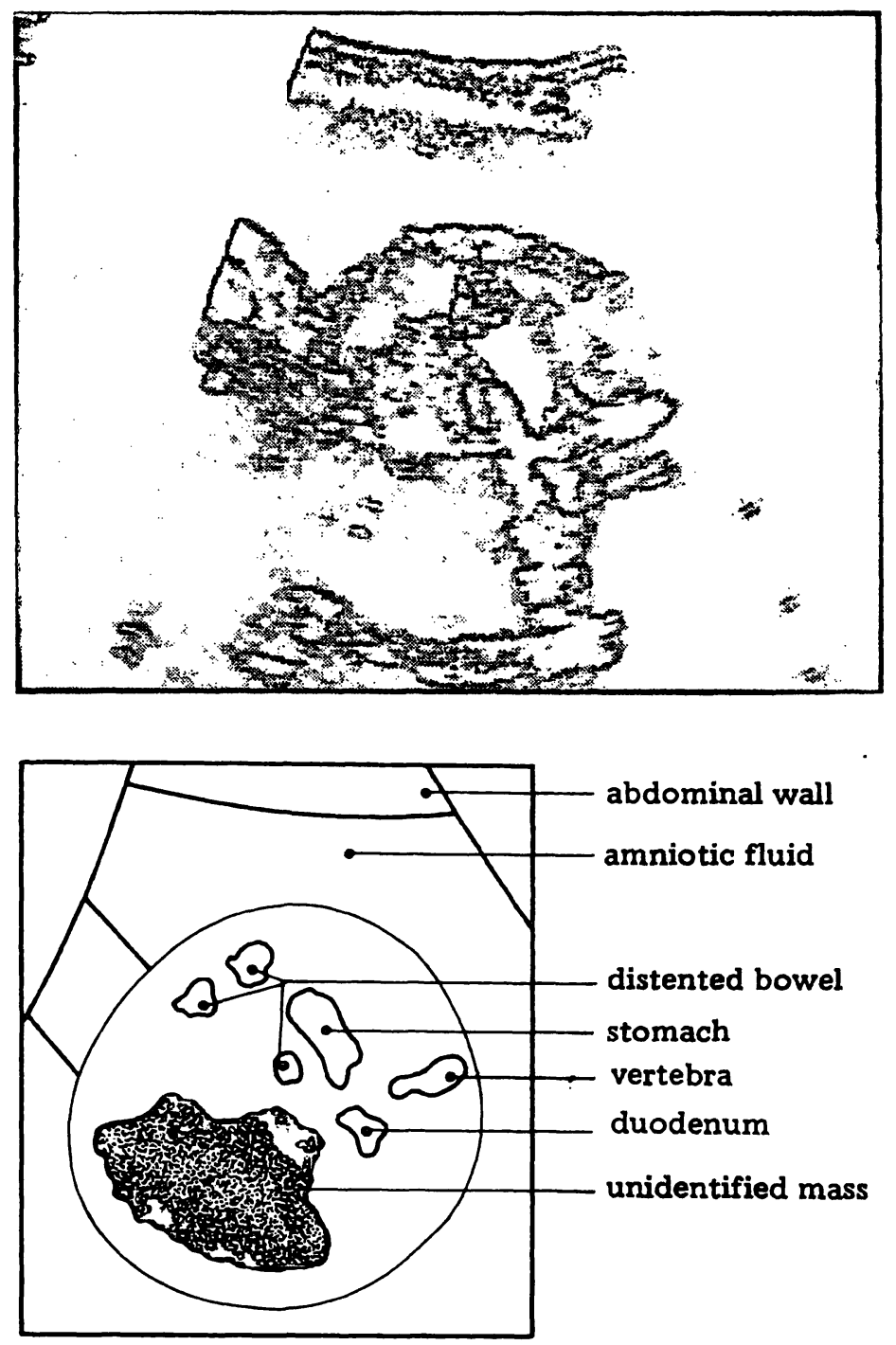

Fig. 2. Echography at the 9th day of admission.

\section{Discussion}

Atresia of the small bowel is a malformation with an incidence of $1: 12.500-20.000$. Stenosis can be regarded as the less serious form. There are 4 types of obstruction [8].

\section{Type 1: a septum.}

Type 2: a fibrous strand.

Type 3 A: a mesenterial defect with or without a fibrous strand. The total length of the bowel is subnormal.

Type 3 B: the "apple-peel" or "Christmas tree" atresia. The superior mesenteric artery and most of the jejunum are absent. The remainder of the bowel is twisted around the interior mesenteric artery.
Type 4: multiple obstructions, frequently combinations of atresia and stenosis.

The pathogenesis of the malformation was suspected when retrospective studies demonstrated a compromise of the blood supply of the bowel during fetal life in many cases. Signs of this were volvulus, intussusception, snaring at the umbilical ring and kinking.

This was confirmed by the experimental work of LOUW and BARNARD [7]. They operated on 45 to 55 day pregnant mongrel bitches and interfered with the bloodsupply of the fetal bowel, partly by ligation of the arterial branches supplying it and partly by creating strangulation obstruction. After 2 days disintegration of the fetal bowel was observed. Subsequently, absorption of dead tissue took place and at about 8 days after the operation only a thin fibrous strand could be found. Finally the proximal bowel became distended. A positive correlation was found between the diameter of the obstructed vessel and the extent of the atresia. When vascular interference was incomplete, stenosis was the result. In the case of strangulation, the blind ends were close together and fused to form a membrane.

TIBBOEL obtained the same results in experiments with chicken embryos [20]. He also proved that a temporary obstruction of the blood supply could result in atresia. This for example could be temporary kinking of an artery during rotation of the bowel or an embolus. In some cases amniocentesis with perforation of the fetal abdomen seemed to be such a cause $[16,18]$. These temporary obstructions can be the reason that disturbances in the blood supply as an etiology are only found in about $25 \%$ of the children with atresia of the small bowel $[6,19]$.

Most of the small bowel atresias develop after organogenesis. This was concluded after bile (not secreted before the 11 th week), planocellular epithelium (not secreted before the 12th week) and lanugo hair (not before the 6th of 7th month) were found distal to the obstruction $[17,19,21]$. It must be noted that the etiology of duodenal atresia is thought to be quite different. Between the 5 th and the 8 th week, about $1 / 3$ of human embryos have a solid stage in the development of 
the duodenum. Recanalization follows afterwards. When this step does not take place, an atresia is the result. Because it is a disturbance of organogenesis, it is easy to understand that duodenal atresia often occurs in combination with other congenital malformations, especially with atresia of the esophagus. In this article we will not further discuss this malformation.

This first symptom our patient had was the fact that she could not feel any fetal movements, which may have been caused by a volvulus. This stress could be reflected in a fetal heartrate tracing with almost no variability and mild decelerations. We have not found this symptom described in the literature before. Polyhydramnios, which is also a cause of reduced sensation of fetal movements, was not present during the first ultrasound scan. Furthermore, our patient felt more fetal movements as the amount of amniotic fluid increased.

In about $20 \%$ of all cases, polyhydramnios is associated with congenital malformations of the fetus [13]. It can be found in about $1 / 3$ of the cases of small bowel atresia, especially when the obstruction is in the upper part of the jejunum. It often represents the first symptom $[5,14]$. Of course, it is possible that the composition of the amniotic fluid is changed by such a malformation. This could not be demonstrated for osmolarity, urea, electrolytes, bilirubin, amylase and lipase [22]. However, DÉLÈZE [1] described two patients with a thirty fold increase of bile salts in amniotic fluid. One woman delivered a child with duodenal atresia and the other one a child with ileal atresia. In both patients the bilirubin values were increased two-fold. This difference could be explained by a greater concentration difference between doudenal and amniotic fluid for bile salts than for bilirubin. Also, the turnover of bile salts in amniotic fluid could be slower than that of bilirubin. Thus, determination of the concentration of bile salts in amniotic fluid is perhaps a method for antenatal detection of small bowel atresia [1].

Another possibility is the determination of disacharidase activity in the amniotic fluid. This enzyme originates from the fetal bowel. In the case of obstruction of the lower part of the bowel, the disacharidase activity decreases [12]. This determination must be performed before the 18 th week of gestation because after this period the fetus stops defecating. The disacharidase activity in the amniotic fluid then drops abruptly.

Small bowel atresia can be suspected by polyhydramnios and diagnosed by fetography. In this way it is also possible to determine the level of obstruction [24]. However, there are no advantages to this method when compared with ultrasonography, a non-invasive method $[2,4,11,23]$. With ultrasound scanning it is easier to diagnose the malformation antenatally because the fetal bowel is filled with amniotic fluid which can be seen as a transsonic space. With B-scanning the distended proximal bowel can be seen as a multilocular transsonic process in the fetal abdomen. With real-time scanning tubular structures are recognizable in which peristaltic movements can be seen, often in two directions. In this way it is possible to differentiate bowel atresia from other malformations such as those of the kidneys, ureters and bladder.

Usually the malformation is diagnosed after birth. If postpartum a gastric aspirate is obtained of more than $25 \mathrm{cc}$ or the child vomits bile within a few hours, the diagnosis should be suspected. A distended abdomen is seen in $80 \%$ of the children with an obstruction distal to the jejunum [10]. In about $2 / 3$ of the cases meconium stool is absent, thus its presence cannot exclude the diagnosis $[8,21]$. The most serious complication is perforation of the bowel accompanied by meconium peritonitits. In about $25 \%$ of all cases perforation and meconium peritonitis are secondary to meconium ileus caused by cystic fibrosis [19]. For this reason a sweat-test was performed twice in our patient, both with a negative result.

When the malformation is diagnosed definitively, surgical correction is necessary. Formerly when a simple resection of the atretic part was performed with an end-to-end, or side-to-side anastomose, the mortality rate was about $90 \%$ because of leakage of the suture, disturbances of wound-healing and secondary obstruction by stenosis. Side-to-side anastomosis also often led to the problems of the "blind loop". After the pathogenesis of the malformation was cleared up it became evident that these complications were caused by an insufficient blood supply of the adjacent bowel parts. Therapy 
Tab. I. Antenatally diagnosis of jejuna- or ilea atresia

\begin{tabular}{|c|c|c|c|c|c|c|}
\hline Year & Author & $\begin{array}{l}\text { Age at ultra- } \\
\text { sonography } \\
\text { and } \\
\text { indication }\end{array}$ & $\begin{array}{l}\text { Age of } \\
\text { delivery } \\
\text { and type }\end{array}$ & Child & Diagnosis & Course \\
\hline 1977 & LEE & $\begin{array}{l}35 \text { weeks } \\
\text { pos. anomaly }\end{array}$ & $?$ & $?$ & atresia IIIB & $?$ \\
\hline 1979 & VON KUNZE & $\begin{array}{l}35 \text { weeks } \\
\text { anomaly. }\end{array}$ & $\begin{array}{l}36 \text { wecks } \\
\text { prim. S.C. }\end{array}$ & o $3350 \mathrm{gr}$ & $\begin{array}{l}\text { small bowel atr. } \\
\text { malrotation }\end{array}$ & $\begin{array}{l}\text { operation. At } 7 \text { th day ileus. } \\
\text { Operated again. Died at the } \\
10 \text { th day of peritonitis. }\end{array}$ \\
\hline 1979 & NIKAPOTA & $\begin{array}{l}32 \text { wceks } \\
\text { routine }\end{array}$ & $?$ & $?$ & small bowel atr. & operation. Good recovery. \\
\hline 1980 & WEISNER & $\begin{array}{l}36 \text { weeks } \\
\text { routine }\end{array}$ & $\begin{array}{l}36 \text { weeks } \\
\text { vaginally }\end{array}$ & $\delta ?$ & $\begin{array}{l}\text { small bowel atr. } \\
\text { microcephaly }\end{array}$ & $\begin{array}{l}\text { operation refused. Died at } \\
\text { the } 7 \text { th day. }\end{array}$ \\
\hline 1984 & BERGMANS & $\begin{array}{l}32 \text { weeks } \\
\text { poly- } \\
\text { hydramnios }\end{array}$ & $\begin{array}{l}33 \text { weeks } \\
\text { sec. C.S. }\end{array}$ & ९ $2200 \mathrm{gr}$ & $\begin{array}{l}\text { ilea atresia } \\
\text { mec. peritonitis }\end{array}$ & $\begin{array}{l}\text { operation within } 24 \text { hours. } \\
\text { Uneventful recovery. }\end{array}$ \\
\hline
\end{tabular}

was changed and subsequently the blind ends were resected liberally. Also because of improved surgical techniques the mortality rate gradually decreased to about $12 \%$. There are some factors which have a significant influence:

- the length of the remaining bowel;

- birthweight: a mortality rate of $6 \%$ for a birthweight above $2.3 \mathrm{~kg}$ and of $23 \%$ for a birthweight under $1.8 \mathrm{~kg}$ [8]. This is important because $20 \%$ of the children with ileal atresia and $66 \%$ of those with jejunal atresia are born prematurely [19]. LUBCHENCO estimates that the mortality rate after 36 weeks of gestation is $2 \%$ for a birthweight of $2.5 \mathrm{~kg}$ and $12 \%$ for a birthweight of $1.5 \mathrm{~kg}$ [9];

- other congenital malformations; mortality rate increases up to $43 \%$ [8];

- meconium peritonitis; mortality rate increase up to $62 \%$ [19];

- delayed diagnosis; if diagnosed after the 4th day, the mortality rate increases to about $24 \%$ [8].

\section{Summary}

A patient was admitted to the hospital in the 31 st week of gestation because of reduced sensation of fetal movements and a pathologic fetal heartrate tracing (Fig. 1). At first no underlying pathology could be found. After a
The question remains as to the benefit of antenatal diagnosis of this malformation. Most authors see the benefit in the awareness it affords the surgeon at birth. Thorough suctionating can promote the expansion of the lungs and prevent serious complications such as aspiration. The operative delay is also minimized. In the literature we found another 4 cases in which the diagnosis of jejuna- or ilea atresia was suspected antenatally by ultrasonography (Tab.I) [3, 4, 10, 23].

It is not possible to extract the proper management from these data. Perhaps termination of pregnancy under favorable circumstances can prevent some of the serious later complications such as perforation and meconium peritonitis. It is also possible that these conditions have already fully developed at the time of diagnosis. We need to acquire more knowledge before the correct management can be determined. Of course this is a general problem. Ultrasonography gives us enormous possibilities for antenatal detection of malformations, and we must learn how to use this knowledge. Therefore, we believe that descriptive case reports are worthwile.

week she developed a polyhydramnios. After repeated ultrasonographic examinations an atresia of the fetal small bowel was suspected (Fig. 2). The diagnosis could be confirmed after birth and on the same day the child 
was operated on. An atresia of the ileum was found. After liberal resection of the atretic part, recovery was complete:

The malformation has an incidence of $1: 12,500-20,000$. The etiology is thought to be a temporary or definite obstruction of a mesenterial artery branch, supplying the small bowel of the fetus. It develops after organogenesis and could be caused by kinking of an artery during rotation, an embolus, amniocentesis, volvulus, intussusception or snaring at the umbilical ring.

Polyhydramnios is the first symptom in about one third of the cases. Diagnosis can be confirmed by fetography or ultrasonography. The latter is preferred because of its non-invasivity. In amniotic fluid, high levels of bile salts (up to thirty times the normal level) have been described in combination with atresia of the small bowel. A diminished disacharidase activity is also ascribed to it.

Most of the time the diagnosis is suspected after birth on the basis symptoms such as a gastric aspirate of more than $25 \mathrm{cc}$, bile vomiting within a few hours, absence of meconium stool or distension of the abdomen. It can be confirmed by X-ray examination. The therapy of choice is liberal resection of the atretic part, because of the reduced bloodsupply of the adjacent bowel part. The mortality rate is about $12 \%$. It is influenced in a negative way by restricted length of the remaining bowel, low birthweight, other congenital malformations, meconium peritonitis and a diagnostic delay of several days until diagnosis.

Four other cases are described in the literature, in which the diagnosis was suspected antenatally by ultrasonography (Tab. I). The proper management during pregnancy cannot be extracted from these data. Most authors see the benefit of antenatal diagnosis in the awareness it affords the surgeon at birth.

With ultrasonography we can detect many congenital malformations antenatally. A discussion on what to do in such cases would be useful.

Keywords: Birth defects, Intestinal atresia, Prenatal diagnosis.

\section{Zusammenfassung}

Angeborene Dünndarmatresie unter geburtshilflichen und neonatologischen Gesichtspunkten

Wegen nachlassender Kindsbewegungen und einem pathologischen Cardiotokogramm (Fig. 1) wurde eine Patientin in der 31. Schwangerschaftswoche in die Klinik eingewiesen. Zunächst war die Ätiologie unklar. Nach wiederholter Ultraschalluntersuchung wurde jedoch der Verdacht auf eine fetale Dünndarmatresie erhoben (Fig. 2). Die Diagnose wurde noch am ersten Lebenstag intraoperativ bestätigt; es handelte sich um eine kongenitale Ileumatresie. Nach großzügiger Resektion des atretischen Abschnittes erholte sich das Kind schnell.

Die Mißbildung tritt mit einer Häufigkeit von 1 : 12 50020000 auf. Ätiologisch vermutet man einen vorübergehenden oder definitiven Verschluß eines Astes der Arteria mesenterica, die den Dünndarm versorgt. Nach der Organogenese kann ein solcher Verschluß durch ein Abknicken der Arterie während der Rotation verursacht werden, aber auch embolisch, durch Amniozentese, einen Volvulus, durch Darmeinstülpung oder durch Einschnürungen am Nabelring.

In einem Drittel der Fälle ist ein Polyhydramnion das erste Symptom. Die Diagnose kann fetoskopisch oder sonographisch bestätigt werden, wobei die Sonographie als nicht-invasives Verfahren bevorzugt wird.

Bei Dünndarmatresien soll der Gehalt an Gallensäuren bzw. deren Salzen im Fruchtwasser bis zu dem Faktor 30 eṛhöht sein. Eine verminderte Disaccharidase-Aktivität wird ebenfalls beschrieben.

In den meisten Fällen wird die Diagnose post partum anhand folgender Symptome gestellt: Aspiration von mehr als $25 \mathrm{cc}$, gallisches Erbrechen innerhalb weniger Stunden, fehlender Mekoniumabgang und ein aufgeblähtes Abdomen. Eine Röntgenaufnahme kann die Diagnose sichern.

Wegen der verminderten Blutversorgung der angrenzenden Dünndarmabschnitte ist eine großzügige Resektion des atretischen Teils die Therapie der Wahl. Die Mortalität beträgt rund $12 \%$. Sie wird durch folgende Faktoren ungünstig beeinflußt: zu kurzer verbliebener Darm, niedriges Geburtsgewicht, Kombination mit anderen kongenitalen Mißbildungen, Mekoniumperitonitis und eine Verzögerung bei der Diagnose post partum.

In der Literatur werden noch 4 weitere Fälle beschrieben, in denen die Verdachtsdiagnose antenatal durch die Sonographie erhoben wurde (Tab. I). Man kann jedoch aus den vorliegenden Daten kein adäquates Vorgehen bei der Schwangerschaftsbetreuung ableiten. Für die meisten Autoren besteht der große Vorteil einer antenatalen Diagnose darin, daß das klinische Personal auf die Mißbildung vorbereitet ist und eingreifen kann.

Immer mehr kongenitale Mißbildungen werden ultrasonographisch antenatal diagnoștiziert. Wir glauben, daß eine Diskussion über die Konsequenzen notwendig ist.

Schluisselwörter: Darmatresien, kongenitale Mißbildungen, pränatale Diagnose.

\section{Résumé}

Aspects obstétricaux et néonataux d'un enfant atteint d'une atrésie de l'intestin grêle

Une patiente, enceinte de 31 semaines, a été hospitalisée à cause d'une perception réduite des mouvements fœtaux et d'un cardiotocogramme pathologique (Fig. 1). Au début, on n'a pas pu mettre en évidence de pathologie importante. Au bout d'une semaine un hydramnios s'est développé. Grâce à des échographies répétées, on a soupçonné une atrésie de l'intestin grêle du fœtus. Après l'accouchement, la nouvelle née préséntait effectivement 
une atrésie de l'iléon. Après ablation ample de la zone sténosée, la guérison a été totale.

Une telle occlusion congénitale de l'intestin grêle se produit dans un cas sur 12500 à 20000 . On considère que la cause provient d'une obstruction temporaire ou définitive d'un artère mésentérique. Cette obstruction se développe après l'organogénèse et elle est peut-être causée par une plicature de l'artère pendant la rotation évolutive, par une embolie artérielle, après une ponction amniotique, par un volvulus ou une invagination, et enfin par une striction au niveau de l'ombilic.

Il existe un excès de liquide amniotique dans $1 / 3$ des cas. La confirmation diagnostique est obtenue par fœtographie ou par échographie, cette dernière méthode étant préférable parce qu'elle n'est pas invasive. On a mentionné un taux élevé (jusqu'à trente fois) des sels biliaires dans le liquide amniotique en cas d'occlusion congénitale de l'intestin grêle. Une activité diminuée de la dissacharidase y est relevée également. Le plus souvent, c'est après la naissance qu'on soupçonne l'existence de cette anomalie; on aspire par exemple plus de 25 centilitres de liquide en provenance de l'estomac, on bien le nouveau-né vomit rapidement après la naissance, ou encore iln'élimine pas de méconium, ou enfin il existe une distention abdominale. Le diagnostic supposé est confirmé par un examen radiographique.

Le meilleur moyen de traiter cette anomalie consiste en une ablation de la partie occluse. Il faut que cette ablation soit ample, parce que la vascularisation des parties voisines est diminuée.

La mortalité est à peu près de $12 \%$. Elle est influencée de façon négative par la longueur diminuée du reste de l'intestin, par une péritonite méconiale et par un délai de quelques jours avant la confirmation du diagnostic.

Dans la littérature on peut trouver quatre autres cas où l'anomalie était soupçonnée par échographie (Tab.I). A partir de ces quelques cas il est impossible de déterminer le traitement correct pendant la grossesse et l'accouchement. La plupart des auteurs soulignent l'avantage d'un diagnostic prénatal afin d'avoir plus d'attention pour la malformation après la naissance.

Deplus en plus à présent on diagnostique des anomalies congénitales pendant la grossesse. L'intention de cet article est de contribuer au débat sur la question de la conduite à adopter en cas d'anomalie congénitale trouvée pendant la grossesse.

Mots-clés: Atrésie intestinale, diagnostic prénatal, malformation à la naissance.

Acknowledgement: The authors thank Prof. Dr. C. FESTEN, pediatric surgeon, for his advice on this manuscript.

Bibliography

[1] DÉlèze, G., D. Sidiroupoulos, G. PAUMGARTNER: Determination of bile acid concentration in human amniotic fluid for prenatal diagnosis of intestinal obstruction. Pediatrics 59 (1977) 647

[2] GEE, H., U. ABDULLA: Antenatal diagnosis of fetal duodenal atresia by ultrasonic scan. Br. Med. J. 4 (1978) 1265

[3] VON KUNZE, G.: Antenale Diagnostik der Darmatresie mit Hilfe der Sonografie. Bbl. Gynäk. 101 (1979) 864

[4] LEE, T. G., B. H. WARREN: Antenatal ultrasonic demonstration of the fetal bowel. Radiology 124 (1977) 471

[5] LLOYD, J. R., H. W. CLATWORTHY: Hydramnions as an aid to the early diagnosis of congenital obstruction of the alimentary tract. Pediatrics 21 (1958) 903

[6] DELORIMIER, A. A., E. W. FONKALSRUD, D. M. HAYS: Congenital atresia of the jejunum and the ileum. Surg. 65 (1969) 819

[7] LOUW, J. H., C. N. BARNARD: Congenital intestinal atresia. Lancet II 19 (1955) 1065

[8] LOUW, J.H., S.CUWES, M.R.Q.DAVIES, et al.: Congenital jejuno-ileal atresia; observations on its pathogenesis and treatment. Z. Kinderchir. 33 (1981) 9

[9] LUBCHENCO, L. O., D. T. SEARLS, J. V. BRAZIE: Neonatal mortality rate: relationship to birthweight and gestational age. J. Pediatr. 81 (1972) 814
[10] NIKAPOTA, V. L. B., C. LOMAN: Gray scale sonographie demonstration of fetal small-bowel atresia. J. Clin. Ultrasound 7 (1979) 307

[11] OPANEY, A. A.: Antenatal diagnosis of congenital gastro-intestinal obstruction by ultrasonsography, a case report. Int. J. Gynecol. Obstet. 19 (1981) 141

[12] POIRTIER, M.: Prenatal detection of intestinal obstruction by disacharidase assay in amniotic fluid. The Lancet 5 (1977) 982

[13] PRITCHARD, J. A.: Fetal swallowing and amniotic fluid volume. Obstet. Gynecol. 28 (1966) 606

[14] QUEenan, J. T., E. C. GaDOW: Polyhydramnions; chronic versus acute. Am. J. Obstet. Gynecol. 1 (1970) 349

[15] RAYBURN, W. F.: Antepartum fetal assesment. Clin. Perinatol. 9 (1982) 349

[16] RICKWOOD, A. M. K.: A case of ileal atresia and ileocutaneous fistula caused by amniocentesis. J. Pediatr. (1977) 312

[17] SANTULlI, T. V., W. A. BLANC: Congenital atresia of the intestine. Pathogenesis and treatment. Ann. Surg. 154 (1961) 939

[18] THER KE LSEN, A. J., H. REHDER: Intestinal atresia caused by second trimester amniocentesis. Br. J. Obst. Gynecol. 88 (1981) 559

[19] TIBBOEL, D., J. C. MOLENAAR: De atresiën van het jejunum, het ileum en het colon; een retrospectieve studie. T. Kindergeneeskunde 49 (1981) 56 
[20] TIBBOEL, D., J. VAN NIE, J. C. MOLENAAR: The effects of temporary general hypoxia and local ischemia on the development of the intestines; an experimental study. J. Pediatr. Surg. 15 (1980) 57

[21] TOUloukIaN, R. J.: Intestinal atresia, Clin. Perinatol. 5 (1978) 3

[22] TOULOUKIAN, R. J.: Composition of amniotic fluid with experimental jejunoileal atresia. J. Pediatr. Surg. 12 (1977) 397

[23] WEISNER, D.: Ultrasonographische Diagnose eines Stenocephalus in Kombination mit einer Dünndarmatresie. Z. Geburtsh. Perinatol. 184 (1980) 445
[24] WHITE, P. R., J. H. STEWART: Radiological diagnosis of fetal foregut abnormalities. Br. J. Radiol. 46 (1973) 706

Received September 19, 1983. Revised March 5, $198 \dot{4}$. Accepted March 15, 1984.

M. G. M. Bergmans, M.D. Bartokstraat 202

N-5011 JD Tilburg

The Netherlands 